\title{
PERAN REGULASI EMOSI TERHADAP KUALITAS HIDUP DENGAN WORK LIFE BALANCE SEBAGAI MEDIATOR PADA PEREMPUAN PERAN GANDA
}

\author{
Gardenia Junissa Siregar $^{1}$, Heryanti Satyadi ${ }^{2}$ dan Rostiana $^{3}$ \\ ${ }^{1}$ Program Studi Magister, Fakultas Psikologi, Universitas Tarumanagara, Jakarta \\ Email: junissadena@gmail.com \\ ${ }^{2}$ Fakultas Psikologi, Universitas Tarumanagara, Jakarta \\ Email: heryanti.satyadi@gmail.com \\ ${ }^{3}$ Fakultas Psikologi, Universitas Tarumanagara, Jakarta \\ Email: rostiana@fpsi.untar.ac.id
}

Masuk : 11-09-2019, revisi: 06-11-2019, diterima untuk diterbitkan : 26-11-2019

\begin{abstract}
ABSTRAK
Kualitas hidup merupakan aspek yang penting dalam kehidupan, terlebih lagi untuk perempuan yang telah menjadi ibu. Regulasi emosi merupakan strategi yang dilakukan untuk merespon emosi yang terjadi. Secara teoritis regulasi emosi dapat dikatakan berperan untuk menentukan kualitas hidup, namun penelitian menemukan hasil berbeda, di mana hubungan ke dua variabel tersebut dinyatakan cukup lemah. Work life balance merupakan keadaan ketika seseorang dapat menyeimbangkan perannya sebagai pekerja dan di dalam keluarga. Oleh karena itu, penelitian ini bertujuan untuk melihat peran regulasi emosi terhadap kualitas hidup dengan work life balance sebagai mediator. Populasi dalam penelitian ini adalah para perempuan peran ganda, yang memiliki aktivitas keseharian, selain menjadi ibu dan istri di dalam keluarga. Teknik pengambilan sampel yang digunakan adalah purposive sampling dengan jumlah sampel sebanyak 400 orang perempuan peran ganda. Penelitian ini menggunakan tiga alat ukur, yaitu World Health Organizational Quality of Life (WHOQOL-BREF), Emotion Regulation Questionnaire (ERQ) dan Work Life Balance Scale (WLBS). Pengujian model penelitian dilakukan dengan menggunakan Path Analysis Structural Model menggunakan LISREL 8.80. Hasil pengujian model menunjukan bahwa work life balance dapat berperan sebagai mediator dengan nilai ( $p$-value $>0.05$ ) yaitu $p$-value 1.000 sehingga model dapat dikatakan berada pada kategori good fit. Hasil nilai standardized solution untuk peran regulasi emosi terhadap kualitas hidup yang awalnya sebesar 0.10 juga mengalami peningkatan menjadi 0.1224 . Sehingga dapat mengindikasikan bahwa peranan regulasi emosi terhadap kualitas hidup akan lebih besar, ketika para perempuan peran ganda memiliki work life balance.
\end{abstract}

Kata kunci: kualitas hidup, regulasi emosi, work life balance, perempuan peran ganda

\begin{abstract}
Quality of life is an important aspect of life, especially for women who have become mothers. Emotion regulation is a strategy undertaken to respond to emotions that arise. Theoretically, emotional regulation can be said to play a role in determining the quality of life, however, studies found different results, where the relationship between the two variables was stated to be quite weak. Work-life balance is a condition when a person can balance their role as a worker and in the family. Therefore, this study aims to look at the role of emotion regulation on quality of life with work-life balance as a mediator. The population in this study are dual role women, who have daily activities, besides being mothers and wives in the family. The sampling technique used was purposive sampling with a total sample of 400 dual role women. This research uses three measuring instruments, namely World Health Organizational Quality of Life (WHOQOL-BREF), Emotion Regulation Questionnaire (ERQ) and Work Life Balance Scale (WLBS). Research model testing was done using the Path Analysis Structural Model using LISREL 8.80. The model testing result shows that work life balance can act as a mediator with ( $p$-value> 0.05), which is $p$ value 1,000, that the model can be said to be in the good fit category. The results of the standardized solution for the role of emotion regulation on the quality of life which was originally at 0.10 also increased to 0.1224 . It indicates that the role of emotion regulation on quality of life will be greater, when dual role women have work-life balance.
\end{abstract}

Keywords: quality of life, emotion regulation, work life balance, dual role women 


\section{PENDAHULUAN}

\section{Latar Belakang}

Pada zaman sekarang, perempuan lebih banyak menghabiskan waktunya dengan melakukan beragam aktivitas baik di dalam ataupun di luar rumah. Data dari Badan Pusat Statistik, pada tahun 2017 menunjukan bahwa terdapat 60,17\% perempuan bekerja di Indonesia (BPS, 2017). Perempuan pekerja atau yang memiliki berbagai aktivitas lain dan sudah berumah tangga, dapat dikatakan memiliki peran lebih dari satu, yang dapat disebut sebagai peran ganda. Rustiani dalam Silfiana (2012) mengatakan, secara umum peran ganda perempuan dapat diartikan sebagai dua atau lebih peran yang harus dimainkan oleh seorang perempuan dalam waktu yang bersamaan. Menjadi seorang pekerja, tidak lantas membuat para perempuan melupakan kewajibannya dalam mengurus kebutuhan rumah tangga. Ibu merupakan ujung tombak penentu baik atau buruknya seorang anak, sehingga kualitas seorang ibu sangat penting dalam menciptakan keturunan yang berkualitas.

Penelitian yang dilakukan oleh Rice (2012) menunjukkan bahwa wanita yang bekerja berpotensi mengalami stres yang lebih tinggi, hal ini dikarenakan wanita bekerja lebih banyak memiliki konflik dalam menjalankan berbagai peran. Stres yang dialami para perempuan peran ganda, akibat benturan pekerjaan dan kewajiban rumah tangga memiliki efek buruk pada kesehatan, dan akan memengaruhi kualitas kehidupannya (Candrasari, Tamtomo, \& Probandari., 2013). Menurut WHO kualitas hidup merupakan presepsi individu tentang kehidupan dalam konteks budaya dan sistem nilai yang berlaku di tempat tinggalnya yang berhubungan dengan harapan dan standar hidup. Rapini \& Kristiyana (2013) dalam penelitiannya mengungkapkan bahwa perempuan peran ganda yang bekerja di sektor bank merasa peran sebagai pengurus rumah tangga dan sebagai pekerja menimbulkan konflik. Lebih lanjut, konflik yang diakibatkan oleh peran ganda tersebut, memengaruhi kepuasan dan kualitas kehidupan (Anastasia, 2011).

Salah satu faktor yang dapat memengaruhi kualitas hidup adalah kondisi psikologis (Power dalam Lopez \& Snyder, 2003). Menghadapi berbagai konflik yang diakibatkan oleh berbagai peran yang harus dijalankan para perempuan peran ganda dapat memengaruhi kondisi psikologis dan mengakibatkan munculnya berbagai emosi, oleh karena itu kemampuan untuk meregulasi emosi merupakan suatu hal yang sangat penting (Juczynski, 2006). Regulasi emosi menurut Gross (2007) merupakan strategi yang dilakukan secara sadar ataupun tidak sadar untuk mempertahankan, memperkuat atau mengurangi satu atau lebih aspek dari respon emosi yaitu tentang bagaimana emosi tersebut dialami dan diekspresikan. Regulasi emosi merupakan suatu kemampuan adaptif yang merupakan aspek penting dari kualitas hidup (Manju \& Basavarajappa, 2016).

Pada penelitian yang dilakukan oleh Manju \& Basavarajappa (2016) strategi cognitive reappraisal pada regulasi emosi dinyatakan memiliki hubungan positif dengan seluruh aspek kualitas hidup. Meskipun memiliki hubungan yang positif, signifikansi cognitive reappraisal terhadap kualitas hidup hanya sebesar 5,2\%, atau dapat dikatakan lemah. Melalui hasil penelitian tersebut, dapat dinyatakan bahwa regulasi emosi memiliki hubungan yang lemah dengan kualitas hidup. Sedangkan keterampilan untuk mengatur emosi dengan strategi regulasi yang baik, sangat dibutuhkan oleh para perempuan peran ganda untuk dapat meningkatkan kualitas hidup (Maharani, 2017). Syed \& Ali (2006) juga menyatakan bahwa para pekerja wanita sangat membutuhkan kemampuan untuk dapat meregulasi emosi, sebagai upaya menangani lamanya durasi kerja dan tekanan emosional yang dihasilkan dari pekerjaannya.

Secara teoritis regulasi emosi dapat dikatakan berperan penting untuk menentukan kualitas hidup para perempuan peran ganda, namun penelitian-penelitian menemukan hasil yang berbeda, di 
mana hubungan ke dua variabel tersebut dinyatakan cukup lemah. Baron \& Kenny (1986) menyatakan, ketika dua variabel diragukan hubungannya, peneliti dapat memberikan satu variabel lain yang memiliki hubungan dengan satu atau ke dua variabel utama tersebut. Terkait dengan kondisi perempuan peran ganda yang memiliki cukup banyak konflik dalam menjalankan berbagai aktivitas, maka individu peran ganda sangat perlu untuk dapat mengimbangi berbagai peran tersebut. Work life balance merupakan suatu keadaan ketika seseorang mengalami keterikatan dan kepuasan yang seimbang dalam perannya sebagai pekerja dan di dalam keluarga (Greenhaus et al., 2003). Work life balance merupakan hal yang perlu dimiliki oleh para perempuan peran ganda yang memiliki hubungan dengan kualitas kehidupan. Fisher, Bulger \& Smith (2009) menyatakan bahwa kualitas hidup akan tercapai saat individu mampu memiliki keseimbangan, kemudian penelitian yang dilakukan oleh Mayangsari \& Amalia (2018) juga menunjukkan bahwa Work Personal Life Enhancement dapat dinyatakan memiliki pengaruh terhadap kualitas hidup, karena dimensi tersebut mengacu pada sejauh mana pekerjaan dapat meningkatkan kualitas kehidupan. Berdasarkan pemaparan di atas, peneliti dapat menyatakan bahwa work life balance dibutuhkan oleh para perempuan peran ganda, sehingga dapat digunakan sebagai variabel mediator. Work life balance akan menghubungkan regulasi emosi dengan kualitas hidup pada perempuan peran ganda.

\section{Rumusan Masalah}

Berdasarkan latar belakang masalah yang telah dipaparkan, maka rumusan masalah dalam penelitian ini adalah "Apakah work life balance dapat berperan sebagai mediator, untuk meningkatkan peran regulasi emosi terhadap kualitas hidup?".

\section{METODE PENELITIAN}

Partisipan dalam penelitian ini berjumlah 400 partisipan, dengan kriteria 1) Perempuan 2) Memiliki status pernikahan, yaitu menikah atau pernah menikah 3) Memiliki anak 4) Memiliki aktivitas keseharian sebagai karyawan/pekerja, freelancer, pengusaha, atau aktif dalam kegiatan organisasi (seperti pengajian ataupun arisan). Peneliti menggunakan metode kuantitatif, yang berpusat pada fenomena yang aktual secara objektif. Variabel yang diukur akan menggambarkan fakta-fakta masalah yang diselidiki. Kemudian data statistik dan data diri yang diperoleh akan dianalisa menggunakan teori. Teknik pemilihan sampel yang digunakan adalah non-probability. Peneliti menggunakan jenis purposive sampling (sampel ditentukan berdasarkan karakteristik subjek). Peneliti menyebar kuesioner secara online menggunakan Google Forms, sehingga partisipan penelitian dapat menyatakan persetujuan pengisian (informed consent) dan mengisi kuesioner menggunakan gadget. Hal tersebut guna mempermudah partisipan dalam mengisi kuesioner. Penelitian ini menggunakan tiga alat ukur, sebagai berikut:

World Health Organizational Quality of Life (WHOQOL-BREF). Penelitian ini menggunakan alat ukur WHOQOL-BREF yang dikembangkan oleh World Health Organization pada tahun 2004. Alat ukur ini telah diterjemahkan ke dalam Bahasa Indonesia oleh Dr. Ratna Mardiati, Satya Joewana, Universitas Katolik Atma Jaya, Jakarta; Dr. Hartati Kurniadi; Isfandari, Kementrian Kesehatan Indonesia dan Risa Sarastiva, Rumah Sakit Ketergantungan Obat Fatmawati (2007). Pada penelitian ini alat ukur, WHOQOL-BREF diseusaikan dengan subjek, yaitu perempuan peran ganda. Sehingga, peneliti terlebih dahulu melakukan Focus Group Discussion untuk mencaritahu aspek-aspek yang dianggap penting bagi perempuan peran ganda. Hasil dari FGD tersebut, menyatakan bahwa rasa bersyukur dan spiritualitas merupakan aspek penting dalam mengukur kualitas kehidupan bagi perempuan peran ganda. Oleh karena itu, peneliti menambahkan beberapa item pernyataan yang berhubungan dengan aspek-aspek dalam FGD. Dimensi pada alat ukur ini terdiri dari, dimensi fisik yang memiliki 7 item pernyataan, 
dimensi psikologis yang memiliki 15 item pernyataan, dimensi lingkungan yang mempunyai 10 item pernyataan, dimensi sosial yang memiliki 7 item pernyataan dan dimensi spiritual yang memiliki 4 item pernyataan. Setelah dilakukan construct validity dengan menggunakan confirmatory factor analysis second order pada aplikasi LISREL 8.80, terdapat 9 item yang memiliki nilai loading factor dibawah 0.5 sehingga dapat dinyatakan gugur dan tidak digunakan dalam penelitian ini. WHOQOL-BREF memiliki skala 1- 5 untuk masing-masing pernyataan, dengan pilihan jawaban yang telah disesuaikan dengan pernyataan. Hasil dari alat ukur WHOQOL-BREF pada penelitian ini dibagi menjadi lima norma kategori yang dihitung melalui nilai mean empiric sampel penelitian.

Emotion Regulation Questionnaire (ERQ). Penelitian ini menggunakan alat ukur emotion regulation questionnaire yang dikembangkan oleh Gross \& John (2003). Alat ukur ini telah diterjemahkan ke dalam Bahasa Indonesia dan digunakan oleh (Oelfy, 2017). Alat ukur ini terbagi menjadi dua strategi regulasi emosi, pertama adalah cognitive reappraisal yang memiliki 8 item pernyataan dan ke dua adalah expressive suppression yang memiliki 4 item pernyataan. Setelah dilakukan construct validity dengan menggunakan confirmatory factor analysis first order pada aplikasi LISREL 8.80, terdapat 2 item yang memiliki nilai loading factor dibawah 0.5 sehingga dapat dinyatakan gugur dan tidak digunakan dalam penelitian ini. Alat ukur ini terdiri dari skala 1-7 untuk masing-masing pernyataan. Hasil dari alat ukur ERQ pada penelitian ini dibagi menjadi lima norma kategori yang dihitung melalui nilai mean empiric sampel penelitian.

Work Life Balance Scale (WLBS). Penelitian ini menggunakan alat ukur work life balance scale yang dikembangkan oleh Hayman (2005). Alat ukur ini telah diterjemahkan ke dalam Bahasa Indonesia dan digunakan oleh (Pangaribuan, 2017). Alat ukur ini terbagi menjadi tiga dimensi, dimensi pertama adalah work interference personal life yang memiliki 7 item pernyataan, dimensi ke dua adalah personal life interference work yang memiliki 4 item pernyataan dan dimensi ke tiga adalah work personal life enhancement yang memiliki 4 item pernyataan. Setelah dilakukan construct validity dengan menggunakan confirmatory factor analysis second order pada aplikasi LISREL 8.80, terdapat 7 item yang memiliki nilai loading factor di bawah 0.5 sehingga dapat dinyatakan gugur dan tidak digunakan dalam penelitian ini. Alat ukur ini terdiri dari skala 1-5 untuk masing-masing pernyataan. Hasil dari alat ukur WLBS pada penelitian ini dibagi menjadi lima norma kategori yang dihitung melalui nilai mean empiric sampel penelitian.

\section{HASIL DAN PEMBAHASAN}

\section{Hasil}

Hasil dari alat ukur WHOQOL-BREF yang diberikan untuk mengetahui kategori kualitas hidup partisipan, didapatkan nilai mean empirik sebesar 3.7760 dengan nilai standar deviasi 0.6529. Melalui data tersebut, peneliti dapat membuat kategori kualitas hidup partisipan, dengan hasil sebagai berikut: 
Tabel 1

Gambaran Umum Kualitas Hidup

\begin{tabular}{c|cccccc} 
& \multicolumn{1}{c}{$\begin{array}{c}\text { Sangat } \\
\text { Rendah }\end{array}$} & Rendah & Sedang & Tinggi & Sangat Tinggi & Total \\
\hline Kualitas & $\mathrm{n}: 27$ & $\mathrm{n}: 90$ & $\mathrm{n}: 165$ & $\mathrm{n}: 86$ & $\mathrm{n}: 32$ & $\mathrm{n}: 400$ \\
Hidup & $(6.75 \%)$ & $(22.5 \%)$ & $(41.25 \%)$ & $(21.5 \%)$ & $(8 \%)$ & $(100 \%)$
\end{tabular}

Pada Tabel 1, dapat dilihat bahwa para perempuan peran ganda yang menjadi partisipan dalam penelitian ini mayoritas memiliki kualitas hidup pada tingkat sedang. Lebih lanjut, peneliti juga membandingkan nilai rerata dari seluruh dimensi kualitas hidup, dengan hasil sebagai berikut:

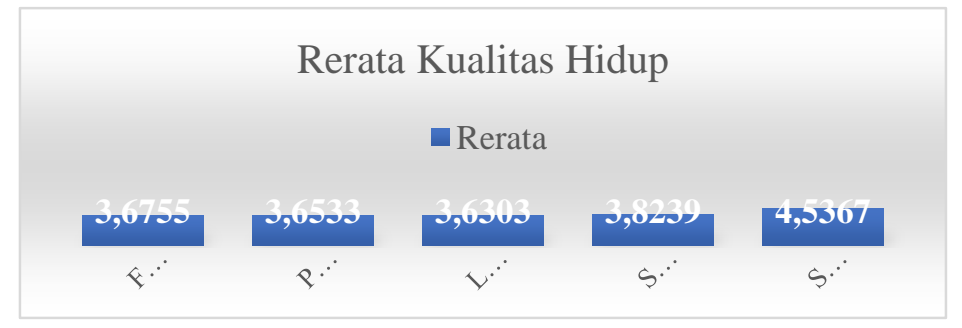

Gambar 1. Rerata Dimensi Kualitas Hidup

Berdasarkan Gambar1, dapat diketahui bahwa seluruh dimensi dalam kualitas hidup, memiliki nilai rata-rata empirik yang berbeda-beda. Dimensi dengan hasil rata-rata tertinggi adalah dimensi spiritual yang dapat menunjukkan bahwa spiritualitas atau keyakinan dan kepercayaan para partisipan merupakan aspek tertinggi dari kualitas hidup. Maka dapat diindikasikan bahwa spiritualitas memiliki peran yang cukup besar terhadap kualitas hidup para partisipan dalam penelitian ini. Hasil tersebut sejalan dengan hasil FGD, yang menunjukan bahwa rasa syukur merupakan aspek penting dalam kualitas kehidupan.

Hasil dari alat ukur ERQ yang diberikan untuk mengetahui kategori regulasi emosi partisipan, didapatkan nilai mean empirik sebesar 4.9554 dengan nilai standar deviasi 0.3898. Melalui data tersebut, peneliti dapat membuat kategori regulasi emosi partisipan, dengan hasil sebagai berikut:

Tabel 2

Gambaran Umum Regulasi Emosi

\begin{tabular}{c|cccccc} 
& Sangat & Rendah & Sedang & Tinggi & Sangat Tinggi & Total \\
\hline Regulasi & $\mathrm{n}: 28$ & $\mathrm{n}: 96$ & $\mathrm{n}: 157$ & $\mathrm{n}: 84$ & $\mathrm{n}: 35$ & $\mathrm{n}: 400$ \\
Emosi & $(7 \%)$ & $(24 \%)$ & $(39.25 \%)$ & $(21 \%)$ & $(8.75 \%)$ & $(100 \%)$
\end{tabular}

Pada Tabel 2, dapat dilihat bahwa para perempuan peran ganda yang menjadi partisipan dalam penelitian ini mayoritas memiliki regulasi emosi pada tingkat sedang, sehingga dapat dikatakan kemampuan regulasi emosi dan strategi regulasi emosi yang digunakan oleh para partisipan sudah cukup.

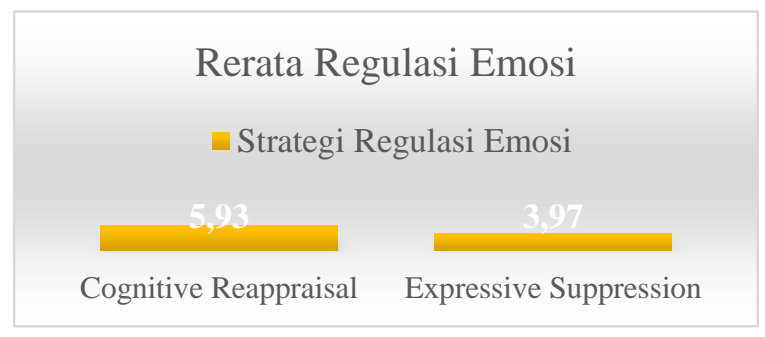




\section{Gambar 2. Rerata Dimensi Regulasi Emosi}

Peneliti juga melakukan analisa perbandingan pada dimensi melalui nilai rata-rata, dapat dinyatakan bahwa nilai rata-rata empirik setiap dimensi berbeda-beda. Rata-rata tertinggi adalah strategi regulasi emosi cognitive reappraisal yang dapat menunjukkan bahwa partisipan mempunyai kecenderungan yang tinggi untuk menggunakan strategi regulasi emosi cognitive reappraisal, dibandingkan strategi expressive suppression. Terdapat 371 partisipan yang memiliki strategi cognitive reappraisal dan 29 partisipan memiliki strategi expressive suppression.

Hasil dari alat ukur WLBS yang diberikan untuk mengetahui kategori work life balance partisipan, didapatkan nilai mean empirik sebesar 3.8728 dengan nilai standar deviasi 0.1873. Melalui data tersebut, peneliti dapat membuat kategori work life balance partisipan, dengan hasil sebagai berikut:

Tabel 3

Gambaran Umum Work Life Balance

\begin{tabular}{|c|c|c|c|c|c|c|}
\hline & $\begin{array}{l}\text { Sangat } \\
\text { Rendah }\end{array}$ & Rendah & Sedang & Tinggi & Sangat Tinggi & Total \\
\hline $\begin{array}{c}\text { Work Life } \\
\text { Balance }\end{array}$ & $\begin{array}{c}\mathrm{n}: 23 \\
(5.75 \%)\end{array}$ & $\begin{array}{c}\mathrm{n}: 87 \\
(21.75 \%)\end{array}$ & $\begin{array}{c}\mathrm{n}: 186 \\
(46.5 \%)\end{array}$ & $\begin{array}{c}\mathrm{n}: 71 \\
(17.75 \%)\end{array}$ & $\begin{array}{c}\mathrm{n}: 33 \\
(8.25 \%)\end{array}$ & $\begin{array}{c}\mathrm{n}: 400 \\
(100 \%)\end{array}$ \\
\hline
\end{tabular}

Pada Tabel 3, dapat dilihat bahwa para perempuan peran ganda yang menjadi partisipan dalam penelitian ini mayoritas memiliki work life balance pada tingkat sedang, sehingga dapat dikatakan work life balance para partisipan dalam penelitian ini cukup.

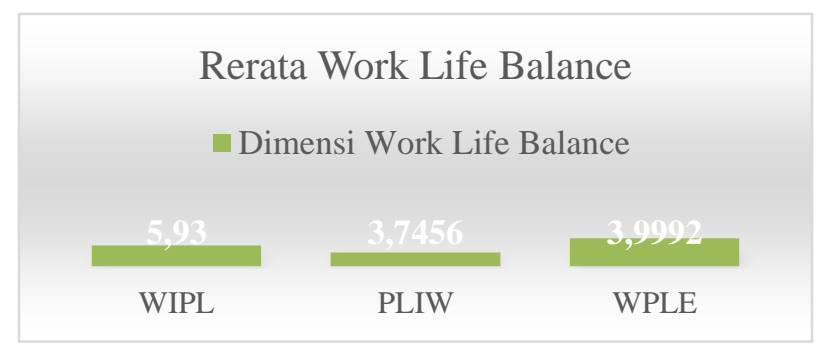

Gambar 3. Rerata Dimensi Work Life Balance

Peneliti juga melakukan analisa perbandingan pada dimensi melalui nilai rata-rata, dapat dinyatakan bahwa nilai rata-rata empirik setiap dimensi berbeda-beda. Rata-rata tertinggi terdapat pada dimensi work personal life enhancement yang dapat menunjukkan bahwa partisipan mempunyai kecenderungan yang tinggi untuk merasa bahwa kehidupan pribadinya dapat meningkatkan kinerja atau aktivitas keseharian yang harus dilakukannya, dan pekerjaan atau aktivitas kesehariannya dapat meningkatkan kualitas kehidupan pribadinya.

Hasil Uji Hipotesis. Untuk dapat menjawab hipotesis dalam penelitian ini, peneliti melakukan uji structural model dengan menggunakan aplikasi LISREL 8.80 dengan hasil path analysis seperti gambar di bawah ini: 


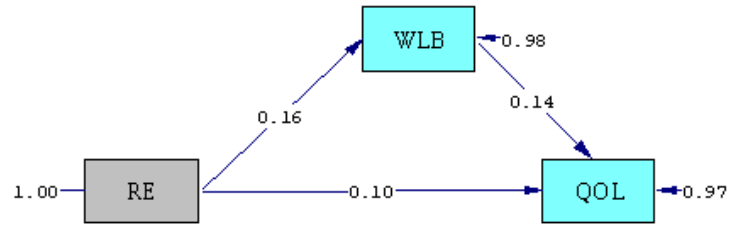

Chi-Square $=0.00, d f=0, P-v a l u e=1.00000$, RMSEA $=0.000$

Gambar 4. Path Analysis Structural Model (Standardized Solution)

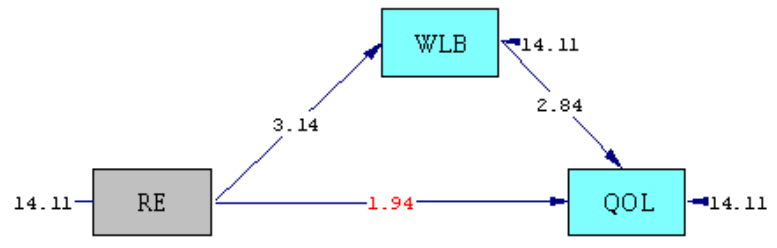

Chi-Square $=0.00, d f=0$, P-value $=1.00000$, RMSEA $=0.000$

Gambar 5. Path Analysis Structural Model (t-value)

Berdasarkan nilai RMSEA sebesar 0.000 dan P-value 1.000 model ini dapat dikatakan memiliki kriteria good fit yang menandakan bahwa model yang dibuat, seuai dengan data empiris yang didapatkan. Kemudian peneliti juga melakukan uji tambahan, untuk melihat sejauh mana variabel mediator yaitu work life balance, memberikan pengaruh kepada hubungan variabel independen yaitu regulasi emosi dengan variabel dependen yaitu kualitas hidup.

\begin{tabular}{|c|c|c|c|}
\hline Input: & & Test statistic: & $p$-value: \\
\hline$t_{\mathrm{a}} 3.14$ & Sobel test & 2.10627941 & 0.03518009 \\
\hline \multirow[t]{3}{*}{$t_{\mathrm{b}} 2.84$} & Aroian test & 2.04987675 & 0.04037646 \\
\hline & Goodman test & 2.16760969 & 0.0301884 \\
\hline & Reset all & \multicolumn{2}{|c|}{ Calculate } \\
\hline
\end{tabular}

Gambar 6. Hasil Uji Sobel Test

Pada hasil Sobel test di atas, dapat dilihat bahwa didapatkan nilai $t$-test Sobel test sebesar 2.106 dengan kriteria ( $t$-value >1.96) maka dapat dikatakan variabel mediator dalam penelitian ini, terbukti dapat menjadi mediator. Selanjutnya, jika dilihat melalui nilai $p$-value Sobel test, juga didapatkan nilai sebesar 0.0351 dengan kriteria (p-value < 0.05 ) yang dapat menyatakan bahwa work life balance dalam penelitian ini, dapat berfungsi secara sempurna sebagai mediator.

Melalui hasil pengujian Structural Model di atas, peneliti dapat mengetahui hasil untuk menjawab hipotesis yang menjadi pertanyaan dalam penelitian ini dengan regulasi emosi sebagai independen variabel, kualitas hidup sebagai dependen variabel dan work life balance sebagai mediator variabel. Selanjutnya, untuk dapat mengetahui besarnya peran regulasi emosi terhadap kualitas hidup, ketika work life balance menjadi mediator diantaranya. Peneliti melakukan perhitungan sebagai berikut:

Tabel 5

Perhitungan Model Struktural

Model Struktural Koefisien
Direct Effects (standardized) (standardized)
Indirect Effects

Total 


$\begin{array}{cccc}\begin{array}{c}\text { Regulasi Emosi -> } \\ \text { Kualitas Hidup }\end{array} & 0.10 & 0.10 & - \\ \begin{array}{c}\text { Regulasi Emosi -> Work } \\ \text { Life Balance }\end{array} & 0.16 & - & - \\ \begin{array}{c}\text { Work Life Balance -> } \\ \text { Kualitas Hidup }\end{array} & 0.14 & 0.0224 & 0.0224 \\ & & (0.16 \times 0.14) & \mathbf{0 , 1 2 2 4}\end{array}$

Melalui Tabel 5, dapat dilihat bahwa work life balance memiliki hubungan sebesar 0.0224 kepada peran regulasi emosi dan kualitas hidup. Peranan regulasi emosi terhadap kualitas hidup yang semula hanya sebesar 0.10 bertambah menjadi 0.1224 dengan adanya sumbangan dari variabel mediator, yaitu work life balance. Maka hasil dari penelitian ini dapat mengindikasikan bahwa peranan regulasi emosi terhadap kualitas hidup pada para perempuan peran ganda akan lebih besar, ketika para perempuan peran ganda memiliki work life balance.

\section{Pembahasan}

Hasil dalam penelitian ini menunjukan kesesuaian dengan penelitian terdahulu, di mana penelitian yang dilakukan oleh Manju \& Basavarajappa (2016) menemukan hasil bahwa regulasi emosi memiliki hubungan positif dengan kualitas hidup, namun dapat dikatakan lemah. Sesuai dengan hasil penelitian tersebut, dalam penelitian ini hubungan langsung antara regulasi emosi dengan kualitas hidup memiliki nilai yang lemah, yaitu 0.10. Hasil tersebut kemudian meningkat ketika peneliti menambahkan work life balance sebagai variabel mediator, yaitu sebesar 0.1224. Melalui hasil penelitian tersebut, dapat dinyatakan bahwa regulasi emosi memiliki hubungan yang lemah dengan kualitas hidup, namun hubungan tersebut dapat meningkat ketika work life balance digunakan sebagai mediator diantaranya.

Gambaran regulasi emosi yang dimiliki oleh para perempuan peran ganda dalam penelitian ini berada pada tingkat kategori sedang, dengan nilai rata-rata dimensi tertinggi adalah cognitive reappraisal. Hasil tersebut dapat mengartikan bahwa para perempuan peran ganda lebih cenderung mengendalikan emosinya secara kognitif, dengan mengubah cara berpikir mereka, terhadap situasi sulit atau situasi yang berpotensi memunculkan emosi, sehingga menghasilkan emosi yang lebih positif (Gross, 2007). Penelitian yang dilakukan oleh Manju dan Basavarajappa (2016) menunjukan bahwa strategi cognitive reappraisal pada regulasi emosi dinyatakan memiliki hubungan positif dengan seluruh aspek kualitas hidup. Maka, hasil penelitian tersebut dapat dikatakan sangat sesuai dengan hasil dalam penelitian ini, di mana perempuan peran ganda yang menggunakan strategi cognitive reappraisal memiliki kualitas hidup yang lebih baik, jika dibandingkan dengan perempuan peran ganda yang menggunakan strategi expressive suppression.

\section{KESIMPULAN DAN SARAN Kesimpulan}

Melalui hasil uji model juga dapat diketahui bahwa work life balance dapat berfungsi sebagai mediator kepada peran regulasi emosi terhadap kualitas hidup. Maka kesimpulan dari hasil penelitian ini adalah regulasi emosi memiliki peran terhadap kualitas hidup pada perempuan peran ganda, namun peran tersebut akan lebih besar saat perempuan peran ganda memiliki kemampuan work life balance yang baik. Oleh karena itu, perempuan peran ganda yang telah memiliki kemampuan untuk meregulasi emosi, dapat dinyatakan tetap membutuhkan work life balance untuk meningkatkan kualitas hidup. 


\section{Saran}

Saran untuk penelitian selanjutnya. Saran pertama, untuk penelitian selanjutnya diharapkan dapat memasukan durasi, lama kerja dan penghasilan pada gambaran partisipan. Saran ke dua, penelitian selanjutnya sebaiknya menggunakan gambaran identitas pekerjaan yang lebih detail, dengan menambahkan durasi kerja dan lama bekerja, serta dapat menggunakan partisipan dengan jenis pekerjaan yang sama. Saran ke tiga, hasil dari penelitian ini menunjukkan hasil yang signifikan dengan structural model yang fit, namun presentase peran antar variabel dapat dikatakan kecil. Oleh karena itu, untuk penelitian selanjutnya, para peneliti diharapkan melakukan penelusuran lebih dalam mengenai variabel regulasi emosi dan hubungannya kepada kualitas hidup, agar pada penelitian selanjutnya didapatkan hasil presentase yang lebih besar lagi.

Saran untuk Perempuan Berperan Ganda. Saran pertama, perempuan peran ganda diharapkan dapat mempertahankan dan lebih mengembangkan kemampuan work life balance. Dengan melakukan beberapa cara berikut, perempuan peran ganda dapat membuat kebijakan untuk dirinya sendiri dengan membuat perencanaan cuti yang terprogram, kemudian membuat kebijakan mengenai jam kerja untuk dapat lebih meluangkan waktu untuk mengurus keluarga. Perempuan peran ganda juga disarankan untuk lebih bijak dalam menggunakan waktu untuk mengerjakan pekerjaan hanya pada jam kerja dan fokus kepada keluarga setelah jam kerja selesai, begitu pula sebaliknya. Saran ke dua, hasil pada penelitian ini juga menunjukkan bahwa perempuan peran ganda yang tinggal bersama keluarga dengan orang tua, memiliki kualitas hidup dan work life balance yang lebih baik. Oleh karena itu, perempuan peran ganda disarankan mempertimbangkan pentingnya layanan penunjuang kehidupan dan pekerjaan, seperti ketersediaan asisten rumah tangga atau keluarga untuk dapat membantu merawat anak pada jam kerja, dapat meringankan beban pikiran perempuan peran ganda. Cara lain yang dapat dilakukan adalah menitipkan anak ke dalam pusat perawatan anak (daycare) terdekat dari lokasi kerja, juga dapat membantu terciptanya keseimbangan. Saran ke tiga, mengikuti fasilitas medis ataupun psikologis seperti mendatangi layanan konseling juga dapat dilakukan untuk meringankan beban peran yang dijalankan para perempuan peran ganda secara psikis, demi menciptakan kondisi psikologis yang lebih terjaga dan untuk menciptakan kualitas kehidupan yang lebih baik.

\section{Ucapan Terima Kasih}

Peneliti mengucapkan terima kasih kepada jajaran manajemen dan karyawan Bank X yang telah bersedia untuk berpartisipasi dalam seluruh proses dalam penelitian ini.

\section{REFERENSI}

Anastasia. (2011). Hubungan Kecerdasan Emosi Dengan Konflik Peran Ganda Pada Karyawan Wanita BRI (Bank Rakyat Indonesia) Yogjakarta. (Skripsi). Universitas Kristen Satya Wacana. Salatiga.

Baron, R. M. and Kenny, D. A. (1986). The moderator-mediator variable distinction in social psychological research: conceptual, strategic, and statistical considerations. Journal of Personality and Social Psychology, 51(6), 1173-1182.

BPS. (2017). Dipetik 8 30, 2018, dari Badan Pusat Statistik: https://www.bps.go.id/dynamictable/2018/08/15/1571/-idg-perempuan-sebagai-tenagaprofesional-menurut-provinsi-2010-2017.html

Candrasari, Tamtomo, \& Probandari. (2013). Perbedaan fungsi keluarga dan kualitas hidup istri Antara istri bekerja dan tidak bekerja. Biomedika, 5(1). 
Fisher, G.G., Bulger, C.A., and Smith, C.S. (2009), Beyond work and family: A measure of work/nonwork interference and enhancement, Journal of Occupational Health Psychology, 14(4), 441-456.

Greenhaus, J. H., Collins, K. M., \& Shaw, J. D. (2003). The relation between work-family balance and quality of life. Journal of Vocational Behavior, 63(3), 510-531.

Gross, J.J \& Thompson, R.A. (2007). Emotion Regulation Conceptual. Handbook of Emotion Regulation, Edited By James J. Gross. New York: Guilfors Publication.

Hayman, J. (2005). Psychometric assessment of an instrument designed to measure work life balance. Research and Practice in Human Resource Management, 13(1), 85-91.

Juczynski, Z. (2006). Health-Related Quality Of Life: Theory and Measurement. Institute Of Psychology University Of Lodz.

Lopez, \& Snyder, C.R. (2003). Positive Psychological Assessment a Handbook of Models \& measures. Washington. DC : APA.

Maharani, A. L. (2017). Regulasi Emosi pada Ibu Bekerja yang Mengalami Konflik Peran Ganda,Yogyakarta: Universitas Sanata Dharma.

Manju, H. K., \& Basavarajappa, S. (2016). Role of emotion regulation in quality of life. The International Journal of Indian Psychology, 4(1), 18. ISSN 2348-5396(e)

Mayangsari, M.D., \& Amalia, D. (2018). Keseimbangan Kerja-Kehidupan Pada Wanita Karir. Banjarbaru : Universitas Lambung Mangkurat.

Oelfy, N. (2018). Penerapan art therapy untuk meningkatkan regulasi emosi pada remaja dengan agresivitas fisik di panti k. Tesis. Jakarta: Universitas Tarumanagara.

Pangaribuan, N. (2017). Peran keseimbangan kerja kehidupan dan presepsi Penambahan beban kerja terhadap kinerja. Tesis. Jakarta: Universitas Tarumanagara

Rapini, T. \& Kristiyana, N. (2013). Dampak Peran Ganda Wanita Terhadap Pola Asuh Anak (Studi pada Wanita Pegawai Lembaga Keuangan Perbankan di Ponorogo). Jurnal Ekuilibrium, 11(2). Universitas Muhammadiyah Ponorogo.

Rice, V. H. (2012) Handbook of stress, coping, and health: Implications for Nursing research, theory, and practice.

Silfiana, F. (2012). Mekanisme koping terhadap konflik peran ganda wanita kerja yang berumah tangga.Jurnal Psikosains. 4(1).

Syed, J., \& Ali, F. (2006). Emotion Regulation and Muslim Women at Work. In book: Consequentiality Volume II: Mythology, Theology, Ontology, Chapter: Emotion regulation and Muslim women at work, Publisher: Tallahassee, Editors: D. Hurst, pp.189-210.

World Health Organization, (1996). WHOQOL-BREF Introduction, Administration, and Generic Version of the Assesment. Retrieved from : http://www.who.int/mental_health/media/en/76.pdf. 